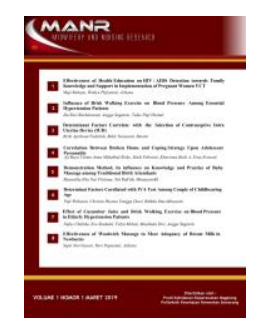

\title{
The Correlation Between Parenting Style And Development Preschool Children
}

\author{
Tia Winda Windar Tika ${ }^{1}$, Dede Gantini², Sinar Pertiwi ${ }^{3}$ \\ E-mail : tiafransisca@gmail.com
}

\begin{abstract}
Background: Family influence in the formation and development of the child's personality is very great because the family is the first social group where children can interact, where children learn and declared themselves as social beings. Families can also provide a basis for the formation of behavior, character, morals, and education for children. Parenting is the attitude of the parents interacts with their children. The purpose of this research was to determine the relationship of parenting parents with the development of preschool children in kindergarten Aisyiah Tawang District of Tasikmalaya.

Methods: the methods used is a quantitative research using a cross-sectional design. The population in this study all students kindergarten in kindergarten Aisyiah Tasikmalaya, preschool, and their parents who totaled 43 people. The sampling technique in this research is using saturation sampling technique, with a total sample of 43 children and their parents.

Results: The results showed that the greatest percentage of parents' parenting preschoolers in kindergarten Aisyiah Tasikmalaya city is with positive parenting, the largest percentage growth of preschool children is to have appropriate development. Statistical test results stated that there is a significant relationship between parenting parents with preschool-age child development.

Conclusion: Most parenting preschoolers in kindergarten Aisyiah Tasikmalaya categorized as positive and progress is being made by his age.
\end{abstract}

Keywords: Parenting; Child Development

1, 2, 3) Poltekkes Kemenkes Tasikmalaya, Indonesia

Jalan Cilolohan No. 35 Kota Tasikmalaya Jawa Barat 46115, Indonesia

Background. Everyone generally going to get married and have children. Children are a surrogate of God that we must guard and our students so that after their big can be a useful person to society, nation, and country and can be happy and proud parents who had painstakingly raised her with love and affection (Septiari, 2012),

Parenting greatly affects the role and functions of the family. Family influence in the formation and development of the child's personality is very great because the family is the first social group where children can interact, where children learn and declared themselves as social beings. Families can also provide a basis for the formation of behavior, character, morals, and education to children (Kartono, 2010).
Every child deserves a decent life for the future of the world depends on them. Many of those do not get the need to grow and thrive. Ranged ten million children die before the age of ten years and more than 200 million children do not develop according to their potential because of an error in parenting a child's basic needs and to grow and develop optimally (UNICEF, 2012 in Hasinuddin \& Fitriah 2013).

The World Health Organization reported that $(5-25 \%)$ or 3 million preschool children suffer minor brain dysfunctions including fine motor developmental disorders. According to (Kay-Lambkin, et al, 2007) globally were reported of children who have disorders of anxiety around (9\%), tempered (11-15\%), conduct disorder (9-15\%). 
According to the $\mathrm{MOH}$ in 2013 (16\%) infants in Indonesia impaired development of motor development, hearing and speech. According to the West Java Health Office in 2016 that the achievement of health care for children under five $(75.9 \%)$ of the target $(85 \%)$ (Health profile Jabar, 2016). According to Tasikmalaya City Health Office that the data obtained in the district of Tawang SDIDTK target for 3009 children, were examined for 1028 children and preschoolers who received growth monitoring $2 x$ as many as 1803 children.

The quality of a child's relationship with his parents is important and affects the development of children, including how their mental health, lifestyle-related health, physical health, social skills, and educational attainment (Simkiss et al, 2013).

Family care during the first five years of life is very influential on 4 domains, namely the development of motor, cognitive, language, social-emotional, and children (Lamb et al Kariger et al, 2013). Children can be said to suffer from developmental delays as a whole when the child has a delay of more than two developmental domains (Ngurah et al, 2010).

Parenting is the attitude of the parents interacts with their children. The attitudes include how parents give the rules, pay attention. Parenting is a treatment of the elderly to meet needs, provide protection and educate children in their daily life. Understanding parenting parents to children is a form of interaction between children and parents during entered care means parents to educate, guide, and protect children (Gunarsa, 2012).

Research conducted by Rahayu (2013) in the village of Pandak, Baturraden subdistrict, Banyumas stated that many studies show that intelligence is achieved at the age of 18 years. According to Bloom in (Musafaroh 2011) children who are in the age range of 0-4 years of intelligence development increased by about (50\%) and the age of 4-8 years developed into an (80\%). It is that the first four years of age are the most defining periods in building a child's intelligence than its aftermath. Failing to get maximum stimulation at that age, the potential development of the child will not be actualized optimally or impaired development of emotional, social, mental, intellectual, and moral.

Another study conducted by Fatimah (2011) shows that there is a relationship between parenting parents with child development in RA Darussalam Sumber Mulyo Jogoroto, Jombang with a significance value of 0.002 or $P<0.05$ and research conducted by Pujiastuti ( 2012) also showed a link between parents' parenting on the development of preschool children in kindergarten Kartika X-9 Cimahi with a significance value of 0.013 or $P<0.05$.

Results of a preliminary study carried out in some kindergartens are located in Tawang District of Tasikmalaya, it is known that in kindergarten Aisyiah through direct observation and interviews with faculty in kindergarten that some children have less reasonable development (diverge) at his age. Such irregularities are visible at rest there are some kids in groups and like fun at the other child but when she is disturbed always does it with violence such as hitting and throwing.

Results of a preliminary study on the pattern of parenting through interviews to parents of students kindergarten Aisyiah Tasikmalaya, about 6 mothers and found that 5 out of 6 people are applying to parent loud enough to their children as parents forbid children to play outside and 1 mother applying to parent follow and respect the child's opinion as giving freedom to children to choose according to their wishes. All of the mothers said that the aspect of social personal like wearing clothes, brushing teeth, and take their food children have been able to do, but sometimes the children still need help from others even though they overall been able to do it alone. Besides, some children have properties that are less socializing with other friends,

Based on the statement above, the authors are interested in researching "parenting 
parents relationship with the development of preschool children in kindergarten Aisyiah located in Tawang District of Tasikmalaya.

Methods. This type of research used in this study is quantitative research using a cross-sectional design. The design of this study used a "cross-sectional" ie where research to study the dynamics of the correlation between risk factors with effects, with the approach, observation, or data collection at a time (Notoatmodjo, 2010). This study aims to determine the relationship of parenting parents with preschool-age child development. The samples are part of the population to be studied or a partial amount of the characteristics possessed by the population (Hidayat, 2007). The sample used in this study were preschoolers and their parents. The sampling technique in this research using the total sampling technique, which in this study sample used was the whole population so that this research is the study population (Hidayat, 2008). Thus, the amount used is 43 children and their parents.

Data were analyzed using univariate and bivariate analysis, a testing technique using the Chi-Square test.

\section{Result and Discussion.}

Table 1.Parenting Parents In Preschooler in kindergarten Aisyiah Tasikmalaya 2019

\begin{tabular}{llll}
\hline No. & Parenting Parents & $\mathrm{f}$ & $\%$ \\
\hline 1 & Positive & 27 & 62.8 \\
2 & Negative & 16 & 37.2 \\
total & & 43 & 100 \\
\hline
\end{tabular}

Table 1 above shows that the largest percentage of parents' parenting preschoolers in kindergarten Aisyiah Tasikmalaya city is with positive parenting as many as 27 people $(62.8 \%)$ and negative parenting patterns that have as many as 16 people (37.2\%).

Table 2. Preschooler development in Tasikmalaya city Aisyiah TK 2019

\begin{tabular}{llll}
\hline No. & Child development & f & $\%$ \\
\hline 1 & Corresponding & 34 & 79.1 \\
2 & question & 9 & 20.9 \\
3 & There deviations & 0 & 0.0 \\
total & & 43 & 100 \\
\hline
\end{tabular}

Table 2 above shows that the largest percentage growth of preschool children in kindergarten Aisyiah Tasikmalaya city is having a corresponding development of as many as 34 people $(79.1 \%)$ and the lowest percentage are those that have dubious developments were 9 people (20.9\%),

Table 3. Relations Parenting Parents with Childhood Development Preschool In kindergarten Aisyiah Tasikmalaya 2019

\begin{tabular}{|c|c|c|c|c|c|c|c|c|c|c|}
\hline \multirow{3}{*}{$\begin{array}{c}\text { Pola } \\
\text { Asuh } \\
\text { Orang } \\
\text { Tua }\end{array}$} & \multicolumn{6}{|c|}{ Perkembangan Anak Usia 4-5 Tahun } & \multirow{2}{*}{\multicolumn{2}{|c|}{ Jumlah }} & \multirow{3}{*}{$\chi^{2}$} & \multirow{3}{*}{ Psyalue } \\
\hline & \multicolumn{2}{|c|}{ Sesuai } & \multicolumn{2}{|c|}{ Meragukan } & \multicolumn{2}{|c|}{$\begin{array}{c}\text { Ada } \\
\text { Penyimpangan }\end{array}$} & & & & \\
\hline & $f$ & $\%$ & $\mathrm{f}$ & $\%$ & $\mathrm{f}$ & $\%$ & $\mathrm{f}$ & $\%$ & & \\
\hline Positif & 25 & 92.6 & 2 & 7.4 & 0 & 0.0 & 27 & 100 & \multirow{3}{*}{8.018} & \multirow{3}{*}{0.018} \\
\hline Negatif & 9 & 56.3 & 7 & 43.8 & 0 & 0.0 & 16 & 100 & & \\
\hline Jumlah & 34 & 79.1 & 9 & 20.9 & 0 & 0.0 & 43 & 100 & & \\
\hline
\end{tabular}

Table 3 above, it can be seen that the cross-tabulation between parenting parents with child development in Tasikmalaya city Aisyiah kindergarten children with positive parenting parents developments largely correspond as many as 25 people or $92.6 \%$, while children with parenting old negative category development largely correspond as many as 9 people (56.3\%)

Based on the statistical test Chi-Square on the relationship between parenting parents with the development of preschool children in kindergarten Aisyiah Tasikmalaya, obtained pvalue $(0,018)$ with $\alpha(0.05)$. Value shows the price pvalue < $\alpha$ lt follows that $\mathrm{HO}$ is rejected means that there is a significant relationship between parenting parents with preschool-age child development.

Based on the results of research on parents' parenting preschoolers in kindergarten Aisyiah Tasikmalaya city obtained the result that most mothers have a positive category parenting with as many as 27 people $(62.8 \%)$. This means that parenting is applied to preschoolers by the period in children.

In parenting parents with positive categories shown that parents give freedom to children to express their feelings and emotions and never require children to be like what parents want but rather give the child freedom to choose, but the restrictions were reasonable

Parenting parents with negative categories shown that parents give freedom to the child even when doing something wrong parents do not give warning.

The results are consistent with Tricia (2010) which states that parenting predicts aggressive behavior or externalization. This 
will result in a parent-child relationship. Parenting parents will shape the character and personality in the development of the child. In other words, the example of a child's behavior problems may result from severe punishment of parents.

Thus the child's behavior can not be separated from parenting applied by parents at home. Family care habits in children are seen in the child's personality. In the field, some children look docile but some are seen as cantankerous.

According to Soekirman in Septiari (2012), parenting is care provided by the mother or other caregiver in the form of attitudes and behavior in terms of proximity to the child, feeding, caring for, maintaining hygiene, give love, and so on. All of the form with the state of the mother in terms of physical and mental health, nutritional status, general education, knowledge of good parenting, role in the family, community, and others.

Based on the results of research on the development of preschool children in kindergarten Aisyiah Tasikmalaya known that most of the development of children according to age, as many as 34 people $(79.1 \%)$. This means that the preschoolers in kindergarten Aisyiah by its time seen that the child can answer questions with the development of screening methods KPSP.

The results are consistent with Hidayat (2015) that the development of children aged 4-6 years in kindergarten Qur'an Saronggi where the child's development largely on the category children's development quite as many as 16 children (51.6\%). Growth includes two events that are different, but interrelated and difficult to separate, ie growth and development. Is it an important development in childhood, because at this time the growth of the base effect and determines the next child development? In infancy, the development of language skills, creativity, health, social, emotional walking briskly (Soetjiningsih, 2011).

The field showed that in children who have developmental doubt the majority of children not yet able to dress themselves fully well, the child still needs help from parents, some children are still not able to follow when instructed to keep a paper is still a lot of wrongs, but it is still there are children who have not been able to jump with one leg a few times without holding.
Based on the results of research on parents' parenting relationship with the development of preschool children in kindergarten Aisyiah Tasikmalaya city is known that the largest percentage of parenting parents positive category with the development of the child by his age as many as 25 people or $92.6 \%$. Results of testing the hypothesis by using statistical test Chi-Square acquired $\rho$ value prices <a, so the conclusion is $\mathrm{HO}$ rejected means that there is a significant relationship between parenting parents with the preschool-age child development.

The results are consistent with Hidayat (2015) which states that based on the results of a statistical test with chi-square test $p$-value of 0.009 is produced value, thus there is a significant relationship between mother's parenting and the development of children aged 4-6 years in kindergarten Qur 'a Saronggi, so the hypothesis that there is an influence of parenting working mothers and mothers do not work against the development of children aged 4-6 years is unacceptable and unsubstantiated.

The field of interaction between parents and children in providing sustainable care from time to time. Parenting applied to the child's parents can influence the prevailing social life in the neighborhood. Kids who are given a good upbringing will have good manners and conversely children who are given care less either will behave less well.

Some of the factors that influence parents to choose the kind of upbringing that they apply by Hurlock (2010), the first of which is the type of parenting they received earlier when parents feel that parenting received before forming individuals who either will apply the type of pattern similar custody of her son. The second factor is the age of the parents, young couples tend to be more democratic and permissive when compared to couples with older young age. The third factor is the socioeconomic status of the middle to the top, this is a common difference in parenting working mothers and mothers who do not work. The fourth factor is a sex educator and sex of the child, the mother is usually more understanding and parents are often more protective of girls.

According to Nursalam (2008) social characteristics, the child begins to play with her friends but no destination group (associative play). In this case, the children 
interact with each other to borrow plaything. As we get older, children begin to play together with the objectives set, for example, the purpose of the competition. Characteristics such game is called with the same game.

Suitability of child development can be influenced by upbringing caregivers or parents, parents who had positive parenting or democratic as it helps develop the child so that the child be herself, respect and support of the child to his opinion, teaching and educating that mistakes and failure are circumstances that we can take lessons to become better able to provide stimulus to the development of children according to age. Besides, parents can involve children to find the best solution and the parents can put trust and confidence in children and can follow or try to enter the child's world.

By contrast, if the caregiver or parent trying to form a subsidiary by the wishes of the parents, try to make the child as a person who always perfect, finding a way out for children if you have a problem, always feel worried or afraid for our children, can make children feel constrained so child development will be disrupted.

Conclusion and Suggestions. Based on the results of research on parents' parenting relationship with the development of preschool children in kindergarten Aisyiah Tasikmalaya can be concluded there is a relationship between parenting parents with the development of preschool children in kindergarten Aisyiah Tasikmalaya. It is suggested that parents pay attention to parenting patterns to support optimal child development
Acknowledgements. Thanks to the researchers say to all those who have helped in completing this research.

\section{References}

Gunarsa, Singgih D. 2008. Psikologi Anak: Psikologi Perkembangan Anak dan Remaja. Jakarta: PT BPK Gunung Mulia.

Hasinuddin \& Fitriah. 2011. Modul Anticipatory Guidance Terhadap Perubahan Pola Asuh Orang Tua Yang Otoriter Dalam Memberikan Stimulasi Perkembangan Anak

Kartono. 2010. Kamus Psikologi. Bandung: Pionir Jaya.

Ngurah. dkk. 2011. Manajemen Penulisan Skripsi, Tesis, dan Disertasi. Jakarta : PT. Raja Grafindo Persada.

Nursalam. 2008. Konsep dan Penerapan Metodologi Penelitian IImu Keperawatan Pedoman Skripsi, Tesis dan Instrumen Penelitian Keperawatan. Jakarta: Salemba Medika

Septiari, B. 2012. Mencetak Balita Cerdas dan Pola Asuh Orang Tua. Yogyakarta: Nuha Medika.

Simkiss Dkk.2013. Walidation Of The Mothers Object Relation Scales In 2-4 Year Old Children And Comparison With The Child Parent Relation Scale. Health And Quolity Of Life Qutcomers.

Soetjiningsih. 2012. Perkembangan Anak dan Permasalahannya dalam Buku Ajar I IImu Perkembangan Anak Dan Remaja. Jakarta : Sagungseto. 